\title{
A note on the geochemistry of some shales from the Bathurst-Newcastle Mining Camp, northern New Brunswick
}

\author{
L.R. Fyffe \\ New Brunswick Department of Natural Resources and Energy, Minerals and Energy Division, \\ P.O. Box 6000, Fredericton, New Brunswick E3B 5H1, Canada
}

Date Received March 7, 1994

Date Accepted May 3, 1994

\begin{abstract}
Ordovician volcanic and sedimentary rocks of the Tetagouche Group in the Bathurst-Newcastle area of northern New Brunswick are host to numerous stratiform sulphide deposits that appear restricted to certain stratigraphic horizons. As a mapping aid in these complexly deformed rocks, shales from some of the recently established formational divisions within the Tetagouche Group were analyzed to determine if they possess specific geochemical signatures that could be used for correlative purposes. Grey and black shales from the Patrick Brook Formation in the lower part of the Tetagouche Group of northern New Brunswick do not exhibit the enrichment in $V$ and $U$ that is characteristic of black shale from the Bright Eye Brook Formation of west-central New Brunswick. Black cherty shales from the Boucher Brook Formation in the upper part of the Tetagouche Group and from the Pointe Verte Formation of the Fournier Group are mildly enriched in V and U. Grey shale from the Boucher Brook Formation is enriched in $\mathrm{Mn}, \mathrm{Zn}, \mathrm{Ni}, \mathrm{Cu}$, and $\mathrm{Co}$, and displays a positive $\mathrm{Ce}$ anomaly and elevated values of light rare-earth elements compared to average shale. This variation in geochemistry reflects a change in depositional conditions from anoxic to oxic between the early and mid-Ordovician and accounts for the abundance of preserved sulphide deposits in the lower part of the Tetagouche Group.
\end{abstract}

Les roches volcaniques et sédimentaires du Groupe de Tétagouche dans la région de Bathurst-Newcastle, dans le nord du Nouveau-Brunswick, sont hôtes de nombreux dépôts de sulfures stratiformes qui semblent être confinés à certains niveaux stratigraphiques. Dans le but de faciliter la cartographie de ces roches à structure complexe, des schistes argileux, provenant des formations récemment établies dans le Groupe de Tétagouche, furent analysés afin de déterminer s'ils possèdent des signatures géochimiques qui pourraient être utilisées à des fins de corrélation. Les schistes argileux gris et noirs de la Formation de Patrick Brook de la partie inférieure du Groupe de Tétagouche du nord du Nouveau-Brunswick ne montrent pas l'enrichissement en $\mathrm{V}$ et $\mathrm{U}$ qui est caractéristique du shale noir de la Formation de Bright Eye Brook du centre-ouest du Nouveau-Brunswick. Les schistes argileux noirs et cherteux de la Formation de Boucher Brook de la partie supérieure du Groupe de Tétagouche et de la Formation de Pointe-Verte du Groupe de Fournier sont légèrement enrichis en $\mathrm{V}$ et $\mathrm{U}$. Le schiste argileux gris de la Formation de Boucher Brook est enrichi en $\mathrm{Mn}, \mathrm{Zn}, \mathrm{Ni}, \mathrm{Cu}$ et $\mathrm{Co}$, et montre une anomalie positive en $\mathrm{Ce}$ et des valeurs élevées de terres rares légères par rapport au schiste argileux moyen. Cette variation de la composition géochimique reflète un changement de conditions de dépôt d'anoxique à oxygénées entre l'Ordovicien précoce et le moyen et explique l'abondance des dépôts de sulfures préservés dans la partie inférieure du Groupe de Tétagouche.

[Traduit par la rédaction]

\section{INTRODUCTION}

Formal stratigraphic divisions have recently been established for the Miramichi and Tetagouche groups of central and northern New Brunswick (van Staal and Fyffe, 1991; van Staal et al., 1992). Defining the boundary between these two groups is of particular interest because stratiform sulphide deposits in the Bathurst-Newcastle Mining Camp are found in association with volcanic rocks that appear to be restricted to the Tetagouche Group. However, rapid facies changes, scarcity of fossils, and complex deformation have prevented a precise correlation of stratigraphic units recognized in various parts of the Miramichi Highlands. Although a disconformity is present at the base of the Tetagouche Group in the type-section near Bathurst in northern New Brunswick (Fyffe, 1976), such a relationship is not apparent elsewhere in the Miramichi Highlands.

A unique geochemical signature is present in black shales immediately underlying volcanic rocks of the Tetagouche Group in the southwestern Highlands near Meductic in west-central New Brunswick (Fyffe and Pickerill, 1993). This signature, defined by anomously high $\mathrm{V}, \mathrm{U}, \mathrm{Mo}, \mathrm{As}$, and $\mathrm{Sb}$ in combination with low $\mathrm{Fe}, \mathrm{Mn}, \mathrm{Co}, \mathrm{Ni}$, and $\mathrm{Zn}$ contents, is related to highly anoxic conditions that existed during high stands of sea level in the early Ordovician (Leggett, 1980; Wilde et al., 1989). The possibility of using this signature and other geochemical characteristics as stratigraphic markers was investigated by sampling various Ordovician black shale units in the Bathurst area. The samples were collected on a field trip in July 1992, organized by Steve McCutcheon and John Langton of the Bathurst Office of the Geological Surveys Branch, New Brunswick Department of Natural Resources and Energy. The field trip was run to familiarize explorationists with the new stratigraphic units recognized in the Bathurst-Newcastle Mining Camp and provided an opportunity to select samples from the type-areas of the Tetagouche and Fournier groups. The small number of samples analyzed in this preliminary study is not claimed to be 
fully representative, but does demonstrate the potential usefulness of shale lithogeochemistry as a stratigraphic mapping guide in the Miramichi Highlands.

\section{Cambrian-Ordoviclan stratigraphy OF NORTHERN NEW BRUNSWICK}

The Cambrian-Ordovician stratigraphy of central and northern New Brunswick records the progressive change from a continental margin to back-arc basin tectonic setting (van Staal et al., 1991, and references therein). The continental margin deposits are represented by a thick sequence of quartzose turbidites assigned to the Miramichi Group (Fig. 1). The turbidites are no younger than early Ordovician based on body fossils in the overlying Tetagouche Group and are unlikely to be older than Cambrian based on the presence of diagnostic trace fossils in correlative rocks in adjacent Maine (Neuman, 1984). The Tetagouche Group in the northern Miramichi Highlands is dominated by a bimodal sequence of rift-related volcanic rocks generated on an active continental margin. Andesites with islandarc geochemical signatures are only abundant in the Meductic area of the southwestern Miramichi Highlands (inset, Fig. 1). An ophiolitic sequence assigned to the Fournier Group, which structurally overlies the Tetagouche Group in northern New Brunswick, has the geochemical characteristics of ocean crust formed in a back-arc environment. Paleontological and radiometric data indicate that back-arc spreading was terminated by the late Ordovician (Ashgillian) (van Staal et al., 1990).

In the Bathurst area, the Miramichi Group is divisible into a lower turbidite sequence dominated by thick-bedded quartzose wackes (Chain of Rocks Formation) and an upper turbidite sequence dominated by shale (Knights Brook Formation). The base of the overlying Tetagouche Group is defined by a thin unit of shallow-water conglomerate, crystalline limestone and calcareous siltstone (Vallee Lourdes Formation) that rests disconformably on turbidites of the Knights Brook Formation below Tetagouche Falls (Fig. 1) on the Tetagouche River. Brachiopods and conodonts date the Vallée Lourdes Formation as middle Arenigian/early Llanvirnian (Fyffe, 1976; Nowlan, 1981; Neuman, 1984).

Dark grey to black shale and interbedded siltstone (Patrick Brook Formation) conformably overlie the Vallée Lourdes Formation on the Tetagouche River and, in turn, are overlain by coarse crystal tuff and fine-grained volcaniclastic beds (Nepisiguit Falls Formation) (Rice and van Staal, 1992). Banded iron formation at the top of the Nepisiguit Falls Formation is associated with many of the stratiform base-metal sulphide deposits in the Bathurst-Newcastle Mining Camp (McAllister, 1960). Late Arenigian/early Llanvirnian U-Pb zircon dates (469 $\pm 2,471 \pm 3 \mathrm{Ma}$ ) from volcanic rocks of the Nepisiguit Falls Formation (van Staal et al., 1992) suggest that the underlying Patrick Brook Formation is largely of late Arenigian age (Fig. 2). A sequence of aphyric to feldspar-phyric rhyolitic lavas and pyroclastic rocks (Flat Landing Brook Formation) overlying the Nepisiguit Falls Formation is Llanvirnian/Llandeilian in age $(466 \pm 2 \mathrm{Ma})$ according to $\mathrm{U}-\mathrm{Pb}$ zircon dating (Sullivan and van Staal, 1990). Interbedded lithic wacke, black shale and chert, and grey, green, and maroon ferromanganiferous shale, and ba-

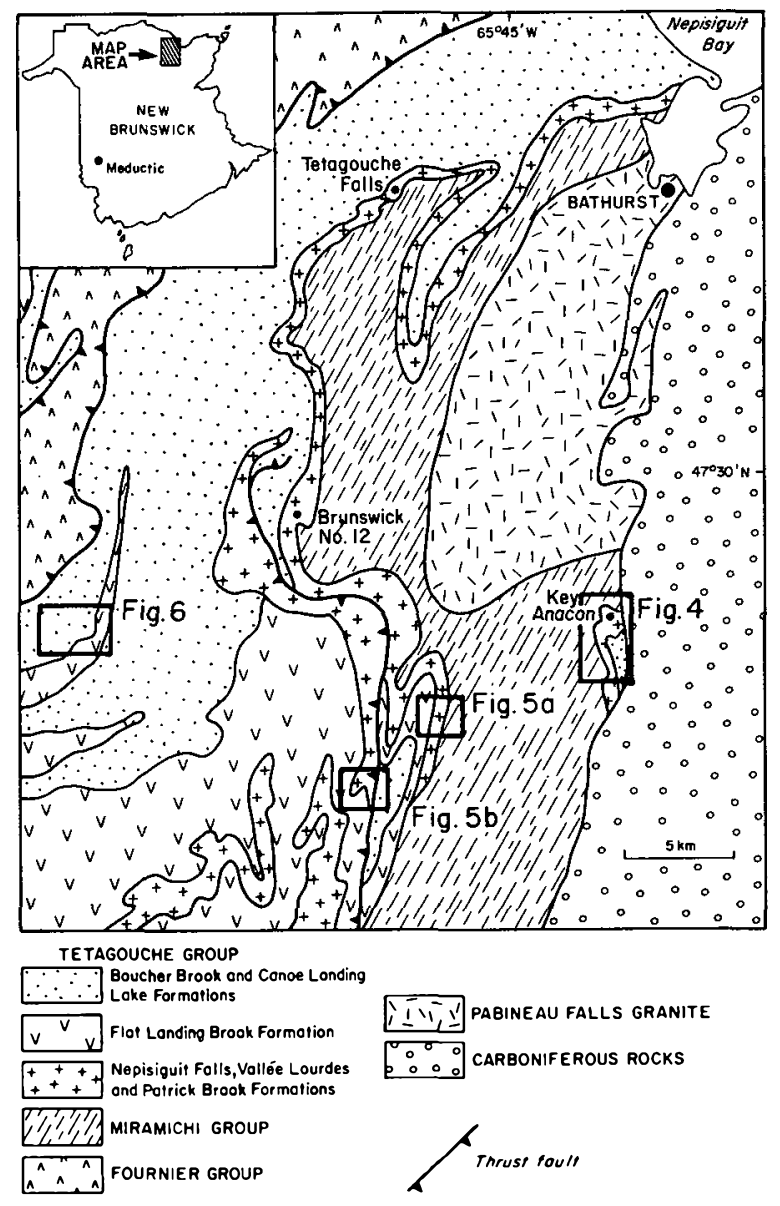

Fig. 1. Geology of the northeastern portion of the Bathurst-Newcastle mining camp, New Brunswick (modified from van Staal and Fyffe, 1991; Sullivan and van Staal, 1993).

salt (Boucher Brook Formation) at the top of the Tetagouche Group contain graptolites of mid-Caradocian age (Skinner, 1974).

A thrust slice containing tholeiitic and alkalic basalt interbedded with ferromanganiferous shale, comendite, and rhyolite (Canoe Landing Lake Formation) structurally overlies the Boucher Brook Formation; a late Arenigian/early Llanvirnian U-Pb age of $470+4 /-2 \mathrm{Ma}$ was obtained for zircon and monazite from the rhyolite (Sullivan and van Staal, 1993). An overlying thrust slice of pillow basalt and gabbro assigned to the Fournier Group is separated from the Canoe Landing Lake Formation of the Tetagouche Group by a basal blueschist zone (van Staal et al., 1990).

In the Meductic area of the southwestern Miramichi Highlands, black shale and siltstone (Bright Eye Brook Formation) in the upper part of the Miramichi Group conformably overlie quartzose turbidites equivalent to the Chain of Rocks Formation in the Bathurst area. The Bright Eye Brook Formation contains high $\mathrm{U}, \mathrm{V}$, and Mo values indicative of a highly reducing depositional environment (Fyffe and Pickerill, 1993). The Bright Eye Brook Formation is followed upward by a sequence of banded iron formation, felsic pyroclastic rocks and andesitic flows (Oak Mountain Formation), and clastic turbidites (Belle Lake Formation) assigned to the Tetagouche Group (van Staal and Fyffe, 1991). 


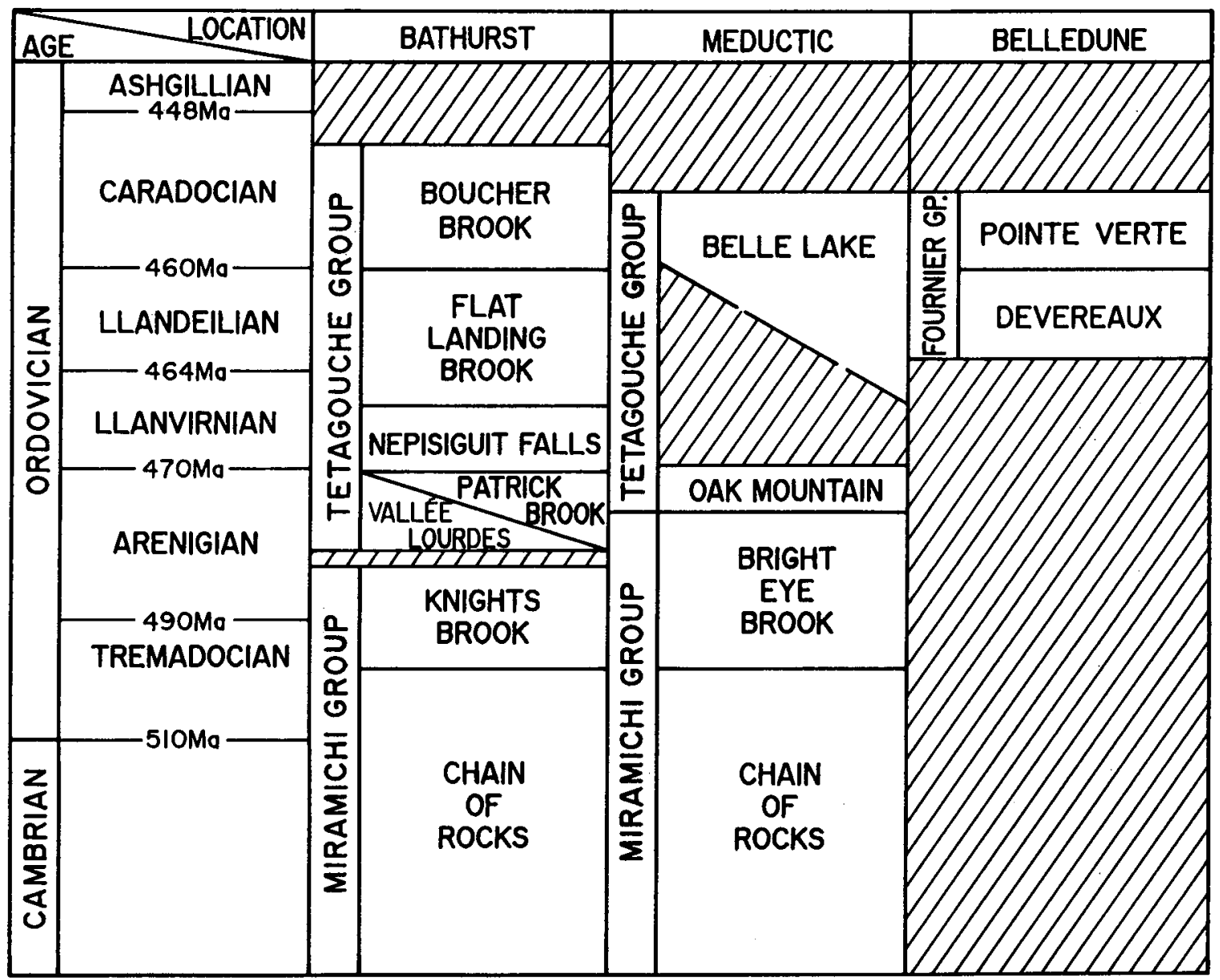

Fig. 2. Stratigraphic columns for Cambrian to Ordovician rocks in the Bathurst area of the northern Miramichi Highlands, in the Meductic area of southwestern Miramichi Highlands, and in the Belledune area of the Chaleur Uplands.

Graptolites from the Bright Eye Brook Formation range in age from late Tremadocian to middle or late Arenigian (Fyffe et al., 1983), indicating that it represents a condensed section encompassing the time of deposition of the Knights Brook Formation and possibly the Vallée Lourdes and Patrick Brook formations as well (Fig. 2). The age of the overlying Oak Mountain volcanic rocks is constrained to the latest Arenigian by a $\mathrm{U}-\mathrm{Pb}$ zircon date $(473 \pm 1 \mathrm{Ma})$ for a cross-cutting intrusive suite (Bevier, 1990) and would, therefore, appear to be slightly older than most volcanic rocks of the Tetagouche Group in the Bathurst area. Early Caradocian graptolites from the Belle Lake Formation indicate that it is in part equivalent in age to the lower part of the Boucher Brook Formation of the Bathurst area (Fyffe et al., 1983). If the Belle Lake Formation correlates with similar rocks found to the northeast of Meductic near Waterville, then its lower boundary probably extends down to the latest Llanvirnian (Nowlan, 1981).

The type-section of Ordovician ophiolitic rocks of the Fournier Group is located in the Belledune area on Chaleur Bay to the northwest of Bathurst (Fig. 3), where it comprises a lower unit of gabbro, plagiogranite and sheeted dykes (Devereaux Formation) and an upper unit of interbedded pillow basalt, feldspathic wacke and shale (Pointe Verte Formation) (Rast and Stringer, 1980; Winchester et al., 1992). U-Pb zircon dating of gabbro (464 $\pm 1 \mathrm{Ma})$ and plagiogranite (461 \pm
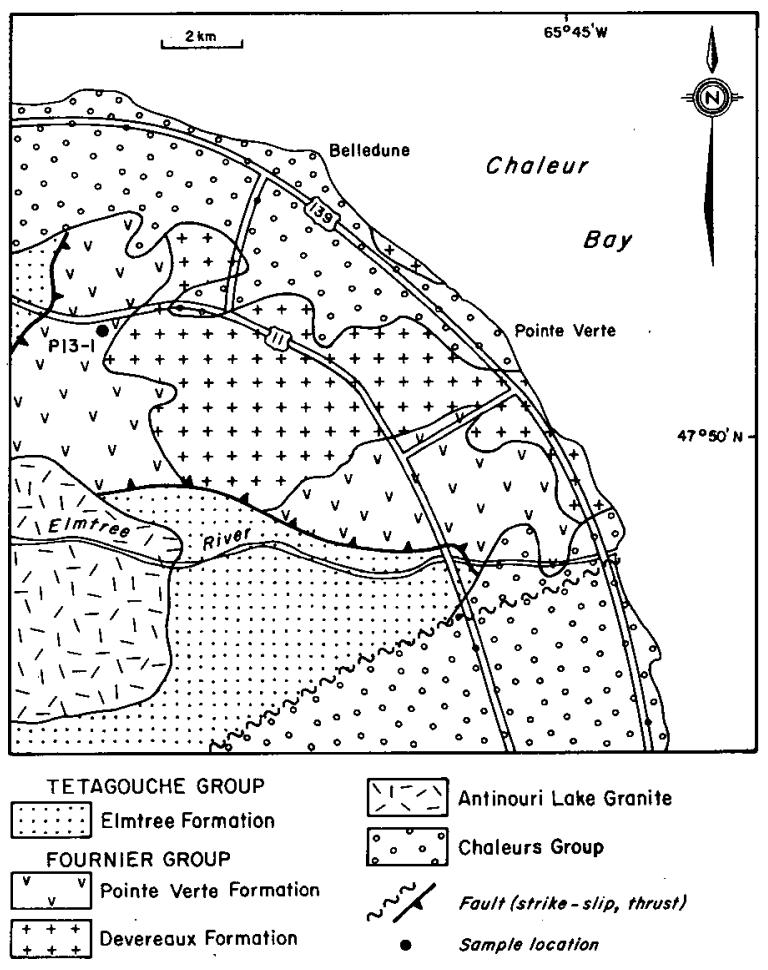

Fig. 3. Geology in the Belledune area of the Chaleur Uplands (modified after Fyffe, 1986; Winchester et al., 1992). 
3, $460 \pm 1 \mathrm{Ma}$ ) provide a Llandeilian age for the Devereaux Formation (Sullivan et al., 1990; Spray et al., 1990). Conodonts and graptolites indicate a Llandeilian to early Caradocian age for the Pointe Verte Formation (Fyffe, 1986).

\section{GEOCHEMISTRY}

Five samples of shale, representing a broad spectrum of the Ordovician stratigraphic column, were collected for chemical analysis - four from the Tetagouche Group (Fig. 1) and one from the Fournier Group (Fig. 3). These were analyzed for 10 major elements, 14 trace elements, and 8 rare-earth elements at the Regional Geochemical Centre at Saint Mary's University, Halifax, Nova Scotia (Table 1). Sample preparation and analytical methods are given in Fyffe and Pickerill (1993).

Samples from the Patrick Brook Formation (Tetagouche Group) include dark grey shale (Sample P5-1) underlying intensely altered tuffs at the Nepisiguit River bridge on Highway 360 near the Key Anacon deposit (Fig. 4), and black pyritic shale (Sample P5-2) immediately below the contact with volcanic rocks of the Nepisiguit Falls Formation on the Nepisiguit River just downstream from the Grand Falls dam (Fig. 5a). For comparative purposes, samples were collected from the Boucher Brook Formation including black cherty shale (Sample P5-3) on the Nepisiguit River below the Narrows (Fig. 5b), and dark grey manganiferous shale (Sample P5-4) exposed in a pit along Nine Mile West Road near Boucher Brook (Fig. 6); and from the graptolite locality in black cherty shale (Sample P13-1) of the Pointe Verte Formation (Fournier Group) on Highway 11 (Fig. 3).

The two analyzed samples from the Patrick Brook Formation differ markedly in major and minor element geochemistry. The composition of Sample P5-1 closely resembles that of average shale as represented by the North American Shale Composite (NASC), except for the lack of a calcium carbonate component (Table 1). The abundance of pyrite in sample P5-2 is reflected in its high Fe content and high loss-on-ignition. Neither sample shows enrichment in $\mathrm{V}$ and $\mathrm{U}$ that characterizes black shales of the Bright Eye Brook Formation in the Meductic area. Although only preliminary sampling has been done at this stage, it would appear unlikely that geochemical studies will enable a precise correlation to be made between the early Ordovician rocks of the Meductic and Bathurst areas on the basis of trace-element content. Nevertheless, the existence of pyriterich sections in parts of the Patrick Brook Formation suggests that ocean waters were relatively reducing throughout the region at this time, consistent with the findings of Goodfellow et al. (1993) based on carbon and sulphur contents. A higher rate of sedimentation in the early Ordovician of northern New Brunswick may account for the restriction of the strong geochemical signature to the Bright Eye Brook Formation of west-central New Brunswick.

The V and U contents in black shale of Sample P13-1 from the Pointe Verte Formation are higher relative to NASC by a factor of 3.7 and 3.0, respectively; $\mathrm{V}$ in black shale of sample P5-3 from the Boucher Brook Formation is higher by a factor of 2.4 (Table 1). Enrichment factors for $\mathrm{V}$ and $\mathrm{U}$ in the Bright Eye
Brook Formation are significantly higher at 16 and 5, respectively. Although the trace-element geochemical signature is less pronounced in the Pointe Verte and Boucher Brook formations, it does, nonetheless, indicate that anoxic conditions existed at least locally in the early and mid-Caradocian.

Sample P5-4 from the Boucher Brook Formation of the Bathurst area is substantially enriched in $\mathrm{Fe}$ and $\mathrm{Mn}$, exhibits no significant enrichment in $\mathrm{V}$, and is mildly depleted in $\mathrm{U}$ relative to NASC (Table 1). The sampled dark grey shale contains $1.60 \% \mathrm{MnO}$, slightly lower than the average $2.13 \% \mathrm{MnO}$ in maroon ferromanganiferous shales found elsewhere in the Boucher Brook Formation (Lentz and Goodfellow, 1993a). A highly oxygenated environment is essential for deposition of manganese-rich sediments (Force and Cannon, 1988) so bottom waters must have become significantly more ventilated by the mid-Caradocian in contrast to the relative anoxic conditions that prevailed during deposition of the Patrick Brook Formation in the late Arenigian. Such a change in redox potential is consistent with the lower $\mathrm{Fe} / \mathrm{Mn}$ values of 7.0 and 5.4, respectively, in the dark grey and maroon shales of the Boucher Brook Formation compared to an average value of 15.8 (hence, relatively weaker oxidizing conditions) found in iron formation of the late Arenigian/early Llanvirnian Nepisiguit Falls Formation (Peter and Goodfellow, 1993; Lentz and Goodfellow, 1993a).

Shales tend to preserve the rare-earth-element (REE) patterns of their source region, indicating that these elements are not generally fractioned during erosion, transportation, and deposition (McLennan, 1989). However, the inherited terrigenous pattern can be modified in the marine environment by processes such as selected precipitation of $\mathrm{Ce}$ from seawater, provided the sedimentation rate is low (Piper, 1974). Shales from the Bathurst area exhibit considerable variation in total REE abundances, much of which can be attributed to the dilution effect of silica (Fig. 7); the cherty nature of sample P 5-3 is evident from its high $\mathrm{Si}$ to $\mathrm{Al}$ ratio. $\mathrm{REE}$ fractionation patterns relative to chondrite for the cherty shales from the Pointe Verte and Boucher Brook formations are approximately parallel to NASC; chondrite-normalized lanthanum to ytterbium ratios $\left(\mathrm{LaN}_{\mathrm{N}} / \mathrm{Yb}_{\mathrm{N}}\right.$ ) are 7.2 and 6.4 , respectively for samples $\mathrm{P} 13-1$ and P5-3, compared to a NASC value of 6.9. The grey shale from the Patrick Brook Formation (Sample P5-1) is moderately depleted in light REE $\left(\mathrm{LaN}_{\mathrm{N}} / \mathrm{Yb}_{\mathrm{N}}=4.2\right)$ compared to NASC, whereas the pyritiferous black shale from the Patrick Brook Formation (Sample P5-2) is severely depleted in light REE (LaN/ $\left.\mathrm{Yb}_{\mathrm{N}}=1.7\right)$ relative to NASC and possesses a marked negative Eu anomaly. (The REE profile of the latter sample was not plotted on Figure 7 to avoid cluttering the diagram.) Depletion of light REE and Eu in the Patrick Brook samples may be related to exhalative activity in the vicinity of the Key Anacon and Brunswick sulphide deposits as these elements have been shown to be mobile under such conditions (Lentz and Goodfellow, 1993b). The high Fe and Mg contents in Sample P5-2 suggest the presence of substantial chlorite, possibly related to hydrothermal alteration.

The mineralogical and textural uniformity of cherts provides a lithology that is well suited for studying marine depositional environments. Because the effects of other variables are 
Table 1. Geochemistry of shale samples from the Tetagouche and Fournier groups.

\begin{tabular}{|c|c|c|c|c|c|c|c|}
\hline Sample & P5-1 & P5-2 & P5-3 & P5-4 & P13-1 & $\mathrm{BE}$ & NASC \\
\hline \multicolumn{8}{|c|}{ Major elements (wt. \%) } \\
\hline $\mathrm{SiO}_{2}$ & 66.61 & 22.60 & 87.41 & 49.73 & 75.58 & 69.61 & 64.80 \\
\hline $\mathrm{Al}_{2} \mathrm{O}_{3}$ & 15.97 & 19.32 & 5.11 & 21.61 & 12.04 & 14.21 & 16.90 \\
\hline $\mathrm{Fe}_{2} \mathrm{O}_{3} \mathrm{~T}$ & 7.64 & 39.70 & 0.44 & 12.50 & 2.58 & 1.65 & 6.28 \\
\hline $\mathrm{MgO}$ & 1.37 & 6.88 & 0.31 & 2.23 & 1.67 & 1.35 & 2.86 \\
\hline $\mathrm{CaO}$ & 0.00 & 0.31 & 0.00 & 0.13 & 0.02 & 0.22 & 3.63 \\
\hline $\mathrm{Na}_{2} \mathrm{O}$ & 0.08 & 0.00 & 0.04 & 0.69 & 0.03 & 0.58 & 1.14 \\
\hline $\mathrm{K}_{2} \mathrm{O}$ & 3.60 & 0.01 & 1.11 & 3.93 & 3.08 & 4.44 & 3.97 \\
\hline $\mathrm{TiO}_{2}$ & 1.03 & 0.59 & 0.20 & 0.90 & 0.56 & 0.83 & 0.70 \\
\hline $\mathrm{MnO}$ & 0.20 & 0.29 & 0.01 & 1.60 & 0.03 & 0.02 & 0.06 \\
\hline $\mathrm{P}_{2} \mathrm{O}_{5}$ & 0.12 & 0.19 & 0.03 & 0.20 & 0.07 & 0.13 & 0.13 \\
\hline L.O.I. & 3.80 & 7.70 & 3.60 & 5.80 & 4.40 & 5.37 & \\
\hline Total & 100.41 & 97.59 & 98.25 & 99.33 & 100.07 & 98.41 & 100.47 \\
\hline
\end{tabular}

Trace elements (ppm)

$\begin{array}{lrrrrrrr}\mathrm{Ba} & 414 & <5 & 148 & 655 & 331 & 7400 & 636 \\ \mathrm{Rb} & 173 & <5 & 44 & 176 & 141 & 168 & 125 \\ \mathrm{Sr} & 13 & <5 & 9 & 50 & 12 & 34 & 142 \\ \mathrm{Y} & 32 & 32 & 13 & 32 & 17 & 31 & (26) \\ \mathrm{Zr} & 323 & 222 & 40 & 113 & 91 & 150 & 200 \\ \mathrm{Nb} & 17 & 16 & <5 & 16 & 8 & 16 & (11) \\ \mathrm{Pb} & <10 & 37 & <10 & 24 & 15 & 25 & (20) \\ \mathrm{Ga} & 20 & 48 & 7 & 24 & 17 & 19 & (19) \\ \mathrm{Zn} & 49 & 56 & 12 & 151 & 46 & 38 & (95) \\ \mathrm{Cu} & 21 & 61 & <5 & 59 & 18 & 19 & (45) \\ \mathrm{Ni} & 14 & 16 & 7 & 72 & 49 & 11 & 58 \\ \mathrm{~V} & 141 & 159 & 310 & 172 & 482 & 2054 & (130) \\ \mathrm{Cr} & 102 & 27 & 67 & 138 & 134 & 138 & 124 \\ \mathrm{Hf} & 10.29 & 7.98 & 1.05 & 3.19 & 2.66 & 4.28 & 6.3 \\ \mathrm{Ta} & 1.41 & 1.44 & 0.22 & 1.03 & 0.45 & 1.34 & 1.1 \\ \mathrm{Th} & 14.64 & 15.72 & 1.93 & 12.24 & 5.89 & 14.94 & 12.3 \\ \mathrm{U} & 3.71 & 4.59 & 4.31 & 1.96 & 8.23 & 13.26 & 2.7 \\ \mathrm{Sc} & 15.62 & 6.04 & 5.85 & 20.83 & 16.18 & 15.29 & 14.9 \\ \mathrm{Co} & 7.09 & 58.81 & 0.39 & 55.59 & 1.60 & 1.57 & 25.7\end{array}$

Rare earth elements (ppm)

\begin{tabular}{lrrrrrrr}
$\mathrm{La}$ & 22.77 & 7.52 & 9.92 & 45.27 & 16.96 & 43.28 & 31.1 \\
$\mathrm{Ce}$ & 50.01 & 18.98 & 20.49 & 118.17 & 31.54 & 92.38 & 66.7 \\
$\mathrm{Nd}$ & 19.99 & 8.23 & 9.37 & 39.53 & 13.97 & 42.94 & 27.4 \\
$\mathrm{Sm}$ & 4.09 & 2.88 & 2.37 & 8.18 & 2.87 & 8.27 & 5.59 \\
$\mathrm{Eu}$ & 1.01 & 0.32 & 0.52 & 1.87 & 0.67 & 1.52 & 1.18 \\
$\mathrm{~Tb}$ & 0.86 & 0.79 & 0.37 & 1.26 & 0.41 & 1.09 & 0.85 \\
$\mathrm{Yb}$ & 3.67 & 3.03 & 1.05 & 3.27 & 1.59 & 4.01 & 3.06 \\
$\mathrm{Lu}$ & 0.53 & 0.48 & 0.15 & 0.44 & 0.27 & 0.60 & 0.46 \\
\hline
\end{tabular}

Notes: P5-1 = Patrick Brook Formation from Nepisiguit River Bridge on Highway 360 P5-2 = Patrick Brook Formation from Grand Falls on Nepisiguit River. P5-3 = Boucher Brook Formation from The Narrows on Nepisiguit River. P5 $4=$ Boucher Brook Formation from Nine-Mile Brook. P13-1 = Pointe-Verte Formation on Highway 11. BE = average composition of Bright Eye Brook Formation at Meductic, New Brunswick (from Fyffe and Pickerill, 1993). NASC = values of North American Shale Composite (from Gromet et al., 1984, except for those in brackets from average shale of Turekian and Wedepohl, 1961). L.O.I. = Loss-On-Ignition. 


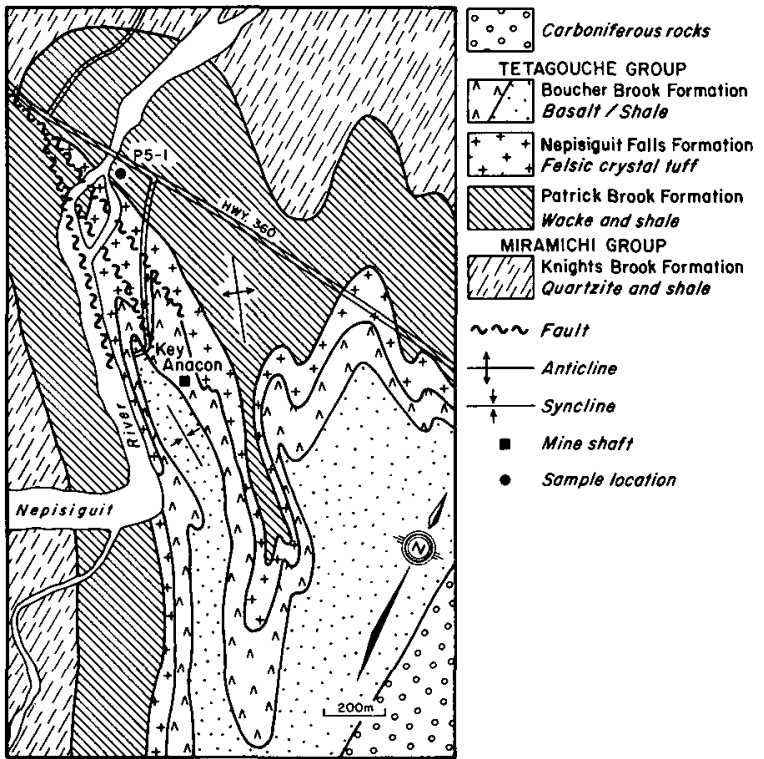

Fig. 4. Detailed geology in the vicinity of the Key Anacon deposit, Bathurst-Newcastle mining camp (modified after Saif et al., 1978) (see Fig. 1 for location).
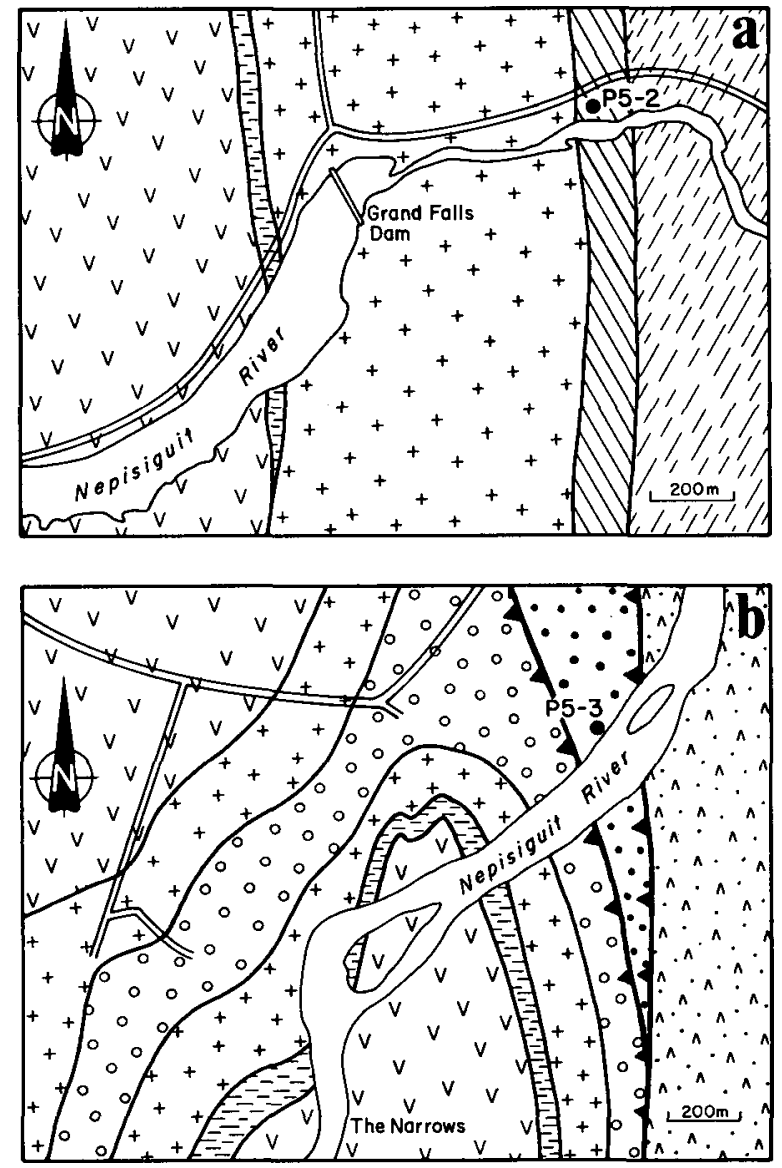

TETAGOUCHE GROUP

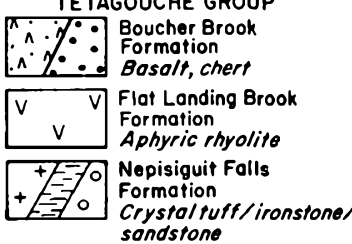

TIIIPatrick Brook Formation MIRAMICHI GROUP TIIIT Knights Brook Formation $1,1,1,1$, Quartzite and shale

- Sample location

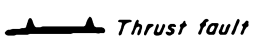

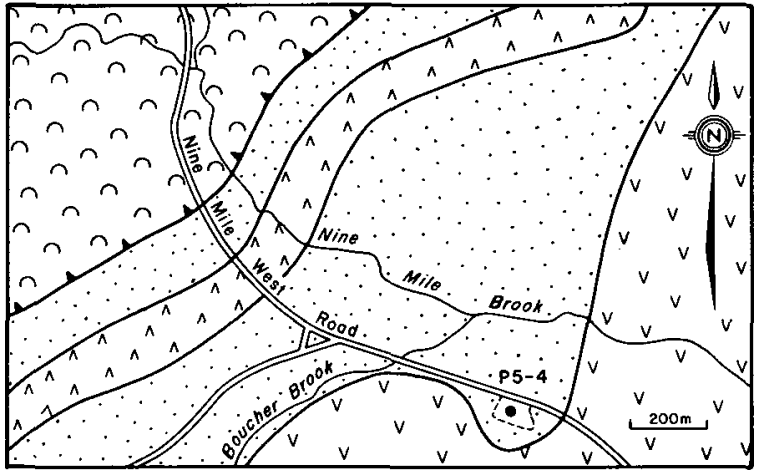

TETAGOUCHE GROUP
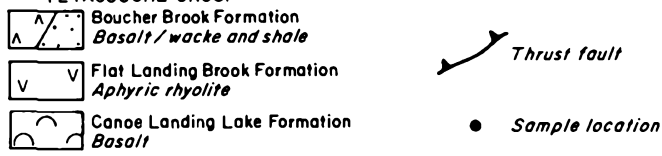

Fig. 6. Detailed geology of the Boucher Brook-Nine Mile Brook area, Bathurst-Newcastle mining camp (modified from van Staal, 1990; McCutcheon and Langton, 1992) (see Fig. 1 for location).

minimized, cherty rocks are most likely to reveal the relative influence of REE included in terrigenous particulate relative to REE absorbed from seawater (Murray et al., 1991). The similarity of the distribution patterns of the cherty shales from the Pointe Verte and Boucher Brook formations noted above indicates a largely terrigenous source for REE in these sediments. Furthermore, their relatively low $\mathrm{LaN}_{\mathrm{N}} / \mathrm{Yb}_{\mathrm{N}}$ values (6.4 and 7.2) suggest a significant marine volcanogenic detrital input compared to continental margin sediments that typically possess higher LaN $/ \mathrm{Yb}_{\mathrm{N}}$ cratonic signatures of about 12 (Bhatia, 1985; Fyffe and Pickerill, 1993).

The grey manganiferous shale from the Boucher Brook Formation (Sample P5-4) contains higher absolute REE abundances than NASC, is relatively more enriched in light REE (LaN/ $\mathrm{Yb}_{\mathrm{N}}=9.3$ ), and displays a small positive Ce anomaly (Fig. 7). Such features are characteristic of sediments containing an hydrogenous REE component precipitated from seawater under oxygenated conditions (Addy, 1979; Thomas et al., 1984). The high $\mathrm{Mn} / \mathrm{Fe}$ and elevated values of $\mathrm{Zn}, \mathrm{Ni}, \mathrm{Cu}$, and Co in Sample P5-4 compared to NASC (Table 1) is consistent with such a depositional setting (Bonatti, 1975; Elderfield et al., 1981). By way of contrast, the absence of $\mathrm{Ce}$ fractionation in the grey and black shales of the Patrick Brook and black shales of Pointe Verte and Boucher Brook formations is consistent with their deposition in an oxygen-depleted environment (Elderfield and Sholkovitz, 1987; Wright et al., 1987). It should be noted that the black shales of the Bright Eye Brook Formation from the Meductic area also lack a $\mathrm{Ce}$ anomaly.

\section{Conclusions}

The preliminary geochemical study on grey and black shales from the Patrick Brook Formation in northern New Brunswick

Fig. 5. Detailed geology along the lower part of the Nepisiguit River, Bathurst-Newcastle mining camp: (a) at Grand Falls and (b) at the Narrows (modified from van Staal, 1990; McCutcheon and Langton, 1992) (see Fig. 1 for locations). 


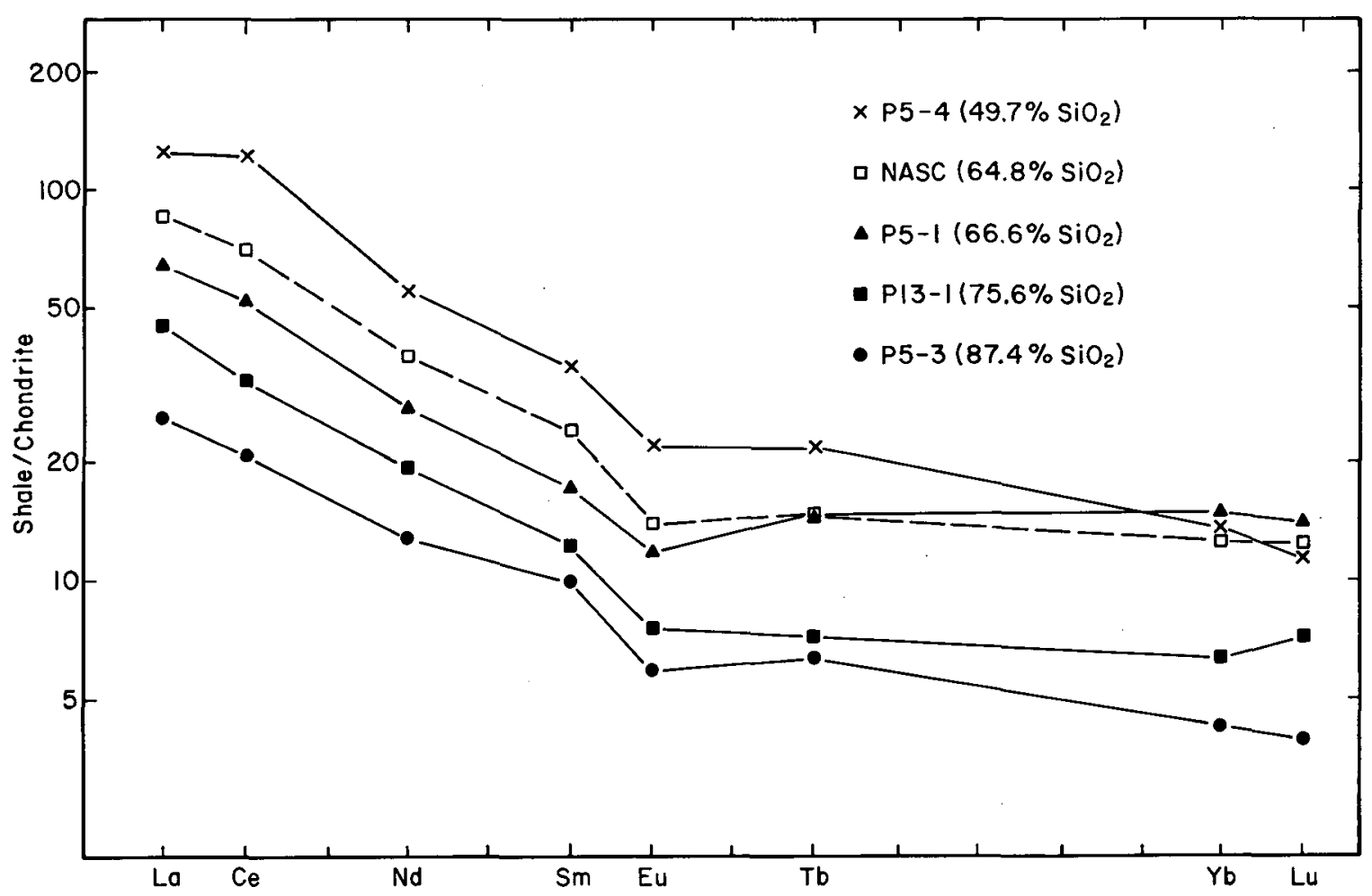

Fig. 7. Rare-earth-element distribution patterns for Patrick Brook Formation (P5-1), Boucher Brook Formation (P5-3, P5-4), Pointe Verte Formation (P13-1), and North American Composite Shale (NASC). Chondrite-normalization values from McLennan (1989).

indicates normal contents of $\mathrm{V}$ and $\mathrm{U}$ compared to the conspicuous enrichment of these elements in black shales of the Bright Eye Brook Formation in west-central New Brunswick. The use of these trace elements to identify an early Ordovician stratigraphic horizon throughout the Miramichi Highlands, therefore, appears to be limited. The absence of a positive $\mathrm{Ce}$ anomaly in the Patrick Brook and Bright Eye Brook formations suggests that variable but widespread anoxic conditions persisted throughout the region between the Tremadocian and late Arenigian - a time interval of approximately 30 million years. Such an environment is a prerequisite for stratiform sulphide deposition and preservation (Turner, 1992) and would account for the large number of these deposits found in the lower portion of the Tetagouche Group. Slight enrichment of $\mathrm{V}$ and $\mathrm{U}$, and lack of a Ce anomaly in the mid-Ordovician black shales of the Pointe Verte and Boucher Brook formations is also consistent with at least local deposition in an anoxic environment. However, elevated $\mathrm{Mn}, \mathrm{Zn}, \mathrm{Ni}, \mathrm{Cu}$, and $\mathrm{Co}$ values associated with a positive $\mathrm{Ce}$ anomaly and enrichment in light and intermediate REE in grey shale of the Boucher Brook Formation indicate a change to more oxic conditions by the midCaradocian. Detailed examination of well exposed stratigraphic sections is presently being undertaken to confirm that these geochemical features will provide a reliable method to distinguish between shales deposited in the lower and upper parts of the Tetagouche Group.

\section{ACKNOWLedgements}

I wish to thank Cees van Staal for discussions on stratigraphic relationships in the Bathurst-Newcastle Mining Camp and Dave Lentz for commenting on an early version of the paper. The constructive criticisms of the two anonymous referees are appreciated. Gerry Johnson drafted the figures and Diane Blair typed the manuscript.

ADDY, S.K. 1979. Rare earth element patterns in manganese nodules and micronodules from northwest Atlantic. Geochimica et Cosmochimica Acta, 43, pp. 1105-1115.

Bevier, M.L. 1990. Preliminary U-Pb geochronologic results for igneous and metamorphic rocks, New Brunswick. In Fourteenth Annual Review of Activities. Edited by S.A. Abbott. New Brunswick Department of Natural Resources and Energy, Mineral Resources, Information Circular 89-2 (second edition), pp. 208-211.

Bhatia, M.R. 1985. Rare earth element geochemistry of Australian Paleozoic greywackes and mudrocks: Provenance and tectonic control. Sedimentary Geology, 45, pp. 97-113.

Bonatti, E. 1975. Metallogenesis at oceanic spreading centers. Annual Review of Earth and Planetary Sciences, 3, pp. 401-431.

Elderfield, H. and Sholkovitz, E.R. 1987. Rare earth elements in the pore waters of reducing nearshore sediments. Earth and Planetary Science Letters, 82, pp. 280-288.

Elderfield, H., Hawkesworth, C.J., Greaves, M.J., and Cälvert, S.E. 1981. Rare earth elements geochemistry of oceanic ferromanganese nodules and associated sediments. Geochimica et Cosmochimica Acta, 45, pp. 513-528.

Force, E.R. and CANNON, W.F. 1988. Depositional model for shallowmarine manganese deposits around black shale basins. Economic Geology, 53, pp. 93-117.

FYFFE, L.R. 1976. Correlation of geology in the southwestern and northern parts of the Miramichi Zone. In 139th Annual Report of the Department of Natural Resources of the Province of New Brunswick, Fredericton, pp. 137-141.

1986. A recent graptolite discovery from the Fournier Group 
of northem New Brunswick. In Eleventh Annual Review of Activities, Project Resumés, 1986. Edited by S.A. Abbott. New Brunswick Department of Natural Resources and Energy, Mineral Resources Division, Information Circular 86-2, pp. 43-45.

FyfFe, L.R. and Pickerill, R.K. 1993. Geochemistry of Upper Cambrian-Lower Ordovician black shale along a northeastern Appalachian transect. Geological Society of America Bulletin, 105, pp. 897-910.

FyFfe, L.R., Forbes, W.H., and Riva, J. 1983. Graptolites from the Benton area of west-central New Brunswick and their regional significance. Maritime Sediments and Atlantic Geology, 19, pp. 117-125.

Goodfellow, W.D., Peter, J.M., and Lentz, D.R. 1993. (Abstract). Modem seafloor hydrothermal systems and their relevance to the genesis of the Bathurst massive-sulfide deposits. Exploration and Mining Geology, 2, pp. 392-395.

Gromet, L.P., DYMEK, R.F., HASKIN, L.A., and Korotev, R.L. 1984. The "North American shale composite": its compilation, major and trace element characteristics. Geochimica et Cosmochimica Acta, 48, pp. 2469-2482.

Leggett, J.K. 1980. British lower Palaeozoic black shales and their palaeo-oceanographic significance. Geological Society of London Journal, 137, pp. 139-156.

LENTZ, D.R. and GOODFELLOW, W.D. 1993a. Geochemistry of the stringer sulphide zone in the Discovery Hole at the Brunswick No. 12 massive sulphide deposit, Bathurst, New Brunswick. In Current Research, Part E, Geological Survey of Canada, Paper 93-1E, pp. 259-269.

1993b. Petrology and mass-balance constraints on the origin of quartz-augen schist associated with the Brunswick massive sulphide deposits, Bathurst, New Brunswick. The Canadian Mineralogist, 31, pp. 877-903.

MCAllister, A.L. 1960. Massive sulphide deposits in New Brunswick Canadian Institute of Mining and Metallurgy, Bulletin 53, No. 573, pp. 88-98.

McCutcheon, S.R. and Langton, J.P. (compilers) 1992. Stratigraphic field course, Bathurst Mining Camp, New Brunswick. New Brunswick Department of Natural Resources and Energy, Geological Surveys Branch, Field Guidebook, 29 p.

McLennan, S.M. 1989. Rare earth elements in sedimentary rocks: influence of provenance and sedimentary processes. In Geochemistry and Mineralogy of Rare Earth Elements. Edited by B.R. Lipin and G.A. McKay. Reviews in Mineralogy, 21, pp. 169-200.

Murray, R.W., Bucholtzen Brink, M.R., Gerlach, D.V., Russ III, G.P., and JONES, D.L. 1991. Rare earth, major, and trace elements in chert from the Franciscan Complex and Monterey Group, California: assessing REE sources to fine-grained marine sediments. Geochimica et Cosmochimica Acta, 55, pp. 1875-1895.

Neuman, R.B. 1984. Geology and paleobiology of islands in the Ordovician Iapetus Ocean: review and implications. Geological Society of America Bulletin, 95, pp. 1188-1201.

Nowlan, G.S. 1981. Some Ordovician conodont faunules from the Miramichi Anticlinorium, New Brunswick. Geological Survey of Canada, Bulletin 345, 35 p.

Peter, J.M. and Goodfellow, W.D. 1993. Bulk and stable sulphur and carbon isotope geochemistry of hydrothermal sediments associated with the Brunswick No. 12 deposit, northern New Brunswick. In Current Research. Compiled and Edited by S.A. Abbott. New Brunswick Department of Natural Resources and Energy, Mineral Resources, Informaton Circular 93-1, pp. 154-169.

PIPER, D.Z. 1974. Rare earth elements in the sedimentary cycle: a summary. Chemical Geology, 14, pp. 285-304.

RASt, N. and Strnnger, P. 1980. A geotraverse across a deformed Ordovician ophiolite and its Silurian cover, northern New Brunswick. Tectonophysics, 69, pp. 221-245.
Rice, R.J. and van StaAl, C.R. 1992. Sedimentological studies in the Ordovician Miramichi, Tetagouche, and Fournier groups in the Bathurst camp and the Belledune-Elmtree Inlier, northern New Brunswick. In Current Research, Part D, Geological Survey of Canada, Paper 92-1D, pp. 257-264.

SAIF, S.I., McAllister, A.L., and MURPHY, W.L. 1978. Geology of the Key Anacon mine area, Bathurst, New Brunswick. CIM Bulletin, 71, pp. 161-169.

SkinNer, R. 1974. Geology of Tetagouche Lakes, Bathurst and Nepisiguit Falls map areas, New Brunswick. Geological Survey of Canada, Memoir 371, 133 p.

Spray, J.G., Flagler, P.A., and Dunning, G.R. 1990. Crystallization and emplacement chronology of the Fournier oceanic fragment, Canadian Appalachians. Nature, 344, pp. 232-235.

Sullivan, R.W. and van StaAl, C.R. 1990. Age of a metarhyolite from the Tetagouche Group, Bathurst, New Brunswick, from U-Pb isochron analyses of zircons enriched in common $\mathrm{Pb}$. In Radiogenic Age and Isotopic Studies: Report 3. Geological Survey of Canada, Paper 89-2, pp. 109-117

1993. U-Pb age of the Canoe Landing Lake Formation, Tetagouche Group, New Brunswick. In Radiogenic Age and Isotopic Studies: Report 7. Geological Survey of Canada, Paper 932, pp. 39-43

Sullivan, R.W., van StaAl, C.R., and Langton, J.P. 1990. U.Pb zircon ages of plagiogranite and gabbro from the ophiolitic Devereaux Formation, Fournier Group, northeastern New Brunswick. In Radiogenic Age and Isotopic Studies: Report 3. Geological Survey of Canada, Paper 89-2, pp. 119-122.

Thomas, J., Carpenter, M.S.N., Colley, S., Wilson, T.R.S., Elderfield, H., and KENNEDY, H. 1984. Metal accumulation rates in northwest Atlantic pelagic sediments. Geochimica et Cosmochimica Acta, 48, pp. 1935-1948.

Turekian, K.K. and Wedepohl, K.H. 1961. Distribution of the elements in some minor units of the Earth's crust. Geological Society of America Bulletin, 72, pp. 175-192.

TURNER, R.J.W. 1992. Formation of Phanerozoic stratiform sedimenthosted zinc-lead deposits: evidence for the critical role of ocean anoxia. Chemical Geology, 99, pp. 165-188.

van StaAl, C.R. 1990. Geology of the northern Miramichi Highlands (scale 1:50 000). New Brunswick Department of Natural Resources and Energy, Mineral Resources, Plate 90-35.

van StaAl, C.R and FyfFe, L.R. 1991. Dunnage and Gander zones, New Brunswick: Canadian Appalachian region. New Brunswick Department of Natural Resources and Energy, Mineral Resources, Geoscience Report 91-2, 39 p.

van StaAl, C.R., Ravenhurst, C.E., Winchester, J.A., Roddick, J.C., and LANGton, J.P. 1990. Post-Taconic blueschist suture in the northern Appalachians of northern New Brunswick. Geology, 18, pp. 1073-1077.

van StaAl, C.R., Winchester, J.A., and BÉDARD, J.H. 1991. Geochemical variations in Middle Ordovician volcanic rocks of the northern Miramichi Highlands and their tectonic significance. Canadian Journal of Earth Sciences, 28, pp. 1031-1049.

van StaAl, C.R., Fyffe, L.R., Langton, J.P., and McCutcheon, S.R. 1992. The Ordovician Tetagouche Group, Bathurst Camp, northem New Brunswick, Canada: history, tectonic setting, and distribution of massive-sulphide deposits. Exploration and Mining Geology, 1, pp. 93-103.

Wilde, P., Quinby-Hunt, M.S., BerRY, W.B.N., and ORTh, C.J. 1989. Palaeo-oceanography and biogeography in the Tremadoc (Ordovician) Iapetus Ocean and the origin of the chemostratigraphy of Dictyonema flabelliforme black shales. Geological Magazine, 126, pp. 19-27.

Winchester, J.A., van StaAl, C.R., and LANGton, J.P. 1992. The Ordovician volcanics of the Elmtree-Belledune inlier and their rela- 
tionship to volcanics of the northern Miramichi Highlands, New

Brunswick. Canadian Journal of Earth Sciences, 29, pp. 1430 -

1447.
Wright, T., Schrader, H., and Holser, W.T. 1987. Paleoredox variations in ancient oceans recorded by rare earth elements in fossil apatite. Geochimica et Cosmochimica, 51, pp. 631-644. 